\title{
Anti-ErbB2/Anti-ErbB3 Bispecific Monoclonal Antibody MM-111
}

National Cancer Institute

\section{Source}

National Cancer Institute. Anti-ErbB2/Anti-ErbB3 Bispecific Monoclonal Antibody MM-

111. NCI Thesaurus. Code C85486.

\begin{abstract}
A bispecific monoclonal antibody directed ag ainst the human epidermal growth factor receptors ErbB2 (Her2) and ErbB3 (Her3) with potential antineoplastic activity. The antiErB2 targeting arm of anti-ErbB2/anti-ErbB3 bispecific monoclonal antibody MM-111 binds to ErbB2 on tumor cells with high affinity while the anti-Erb3 therapeutic arm binds to ErbB3, which may result in the inhibition of cellular proliferation and differentiation in ErbB2-overexpressing tumor cells via inhibition of ErbB3-dependent signal transduction pathways. ErbB2 and ErB3 are members of the epidermal growth factor receptor (EGFR) family of receptor tyrosine kinases and are frequently overexpressed in solid tumors.
\end{abstract}

